\title{
PROFIL FITOKIMIA DAN UJI ANTIBAKTERI BIJI MANGGA ARUM MANIS (Mangifera indica. Linn)
}

Zulhipri, Yusnetty Boer, Resa Rahmawatie, Siti Julekha

Jurusan Kimia, Fakultas Matematika dan Ilmu Pengetahuan Alam, Universitas Negeri Jakarta, Rawamangun 13220, Jakarta

*Corresponding author: zulhipri@yahoo.co.id

\begin{abstract}
Abstrak
Telah dilakukan penelitian tentang profil fitokimia dan uji antibakteri dari biji mangga Arum manis (Mangifera indica. Linn). Hasil uji fitokimia dan anlisis kromatografi lapis tipis terhadap ekstrak metanol, menunjukkan bahwa biji mangga Arum manis mengandung senyawa fenolik, flavonoid dan terpenoid dengan kandungan tertinggi senyawa golongan fenolik. Uji antibakteri menunjukan ekstrak metanol ini dapat menghambat pertumbuhan bakteri Escherichia coli dan Staphylococus aureus dengan nilai konsentrasi hambat minimum masing-masing sebesar 2000 dan $250 \mu \mathrm{g} / \mathrm{mL}$
\end{abstract}

Kata kunci: Mangga, fitokimia, antibakteri.

\section{Pendahuluan.}

Pemanfaatan tumbuhan sebagai bahan dasar obat sangat dipengaruhi oleh pengalaman nenek moyang bangsa Indonesia di bidang kesehatan. Berbagai jenis tumbuhan yang sudah banyak digunakan sebagai bahan dasar obat antara lain jahe, ginseng, temu lawak, brotowali, waru, dan lain-lain.

Mangga (Mangifera indica) adalah salah satu dari sekian banyak jenis tumbuhan tingkat tinggi yang tumbuh di Indonesia. Salah satu jenis mangga adalah mangga Arum manis. Komoditas mangga Arum manis di Indonesia tersebar di 30 propinsi di Indonesia, pada tahun 2005 dengan luas areal sekitar 170.000 ha, total produksi mangga yaitu 1.412.884 ton. Produksi mangga yang begitu besar tidak diimbangi dengan pemanfaatan mangga secara baik. Umumnya masyarakat memanfaatkan mangga hanya pada daging buahnya sebagai makanan sedangkan bijnya dibuang saja. Walaupun biji mangga dapat dimanfaatkan sebagai makanan namun pemanfaatannya belum maksimal.[1]

Dari survei fitokimia yang dilakukan, diketahui bahwa biji mangga Arum manis mengandung senyawa metabolit sekunder golongan terpenoid, kuinon, flavonoid, dan fenolik. Senyawa-senyawa metabolit sekunder ini sering dipergunakan sebagai bahan dasar obat-obatan modern. Sebagai contoh, senyawa terpenoid setoksicavikol asetat, merupakan senyawa yang bersifat antitumor dari tumbuhan lengkuas. Artemisin bersifat antimalaria dari tumbuhan Artemisia annua (Compositae). Senyawa ini merupakan jenis seskuiterpen dari golongan terpenoid. Curcumin yang merupakan senyawa fenolik berasal dari kunyit (Curcuma longa) bersifat antiimflamasi dan antioksidan. Senyawa flavonoid, triterpenoid dan saponin adalah senyawa kimia yang memiliki potensi sebagai antibakteri dan antivirus [2]. Sementara itu senyawa alkaloid juga penting bagi industri farmasi karena kebanyakan mempunyai efek fisiologis tertentu [3].

Bertitik tolak dari kandungan metabolit sekunder tersebut, sangat mungkin biji mangga Arum manis mempunyai potensi untuk membunuh atau menghambat pertumbuhan mikroba. Dengan demikian pada penelitian ini telah dilakukan analisis profil fitokimia dan uji aktivitas antibakteri terhadap ekstrak metanol dari biji mangga Arum manis.

\section{Metodologi Penelitian}

Metode penelitian yang digunakan adalah: ekstraksi cara maserasi dengan 
pelarut metanol, analisis uji fitokimia dengan kromatografi lapis tipis [4], sedangkan untuk uji antibakteri dilakukan dengan metoda cakram dan penipisan lempeng agar [5].

Sampel yang digunakan dalam penelitian ini adalah biji mangga Arum manis (Mangifera indica Linn) yang buahnya diperoleh dari pedagang mangga pasar cililitan Jakarta.

Serbuk kering biji mangga sebanyak 0,5 $\mathrm{kg}$ dimaserasi selama 3 hari dengan pelarut metanol, kemudian pelarutnya diuapkan dengan menggunakan rotary evaporator sehingga diperoleh ekstrak kering. Ekstrak yang diperoleh selanjutnya dilakukan uji fitokimia terhadap golongan senyawa alkaloid, flavonoid, fenolik, steroid dan terpenoid. Uji antibakteri dilakukan terhadap bakteri Escherichia coli dan Staphylococus aures.

\section{Hasil dan Pembahasan}

\subsection{Uji fitokimia}

Hasil uji fitokimia terhadap senyawa metabolit sekunder yang terkandung dalam biji mangga Arum manis adah seperti pada Tabel 1.

Tabel 1. Hasil Uji Fitokimia Biji Mangga Arum Manis (Mangifera indica. Linn)

\begin{tabular}{|l|c|c|}
\hline No & Golongan senyawa & Hasil uji \\
\hline & Alkaloid & - \\
\hline & Steroid & - \\
\hline & Terpenoid & ++ \\
\hline & Fenolik & +++ \\
\hline & Flavonoid & + \\
\hline
\end{tabular}

Keterangan tabel : +++ Kanduingan relatif tinggi

$$
\begin{aligned}
& \text { ++ Kandungan relatif sedang } \\
& + \text { Kandungan relatif rendah } \\
& \text { - Tidak terkandung }
\end{aligned}
$$

Dari tabel 1 di atas dapat diketahui bahwa biji mangga harum manis (Mangifera indica Linn) mengandung senyawa golongan fenolik, terpenoid, dan flavonoid. Kandungan positif tiga $(+++)$ pada golongan fenolik menandakan bahwa fenolik dalam biji mangga Arum manis relatif tinggi. Senyawa golongan terpenoid terkandung dalam kadar relatif sedang dan flavonoid terkandung dalam kadar relatif rendah. Sedangkan steroid dan alkaloid tidak terkandung dalam biji mangga Arum manis.

\subsection{Analisis Kromatografi Lapis Tipis (KLT)}

Ekstrak metanol dianalisis menggunakan plat silika gel. KLT awal menggunakan eluen tunggal untuk mengetahui kondisi awal dari ekstrak. Pelarut yang digunakan adalah metanol, etanol, etil asetat, kloroform, diklorometan, dan n-heksana. Hasil analisis KLT dengan eluen tunggal adalah sperti pada Gambar 1.

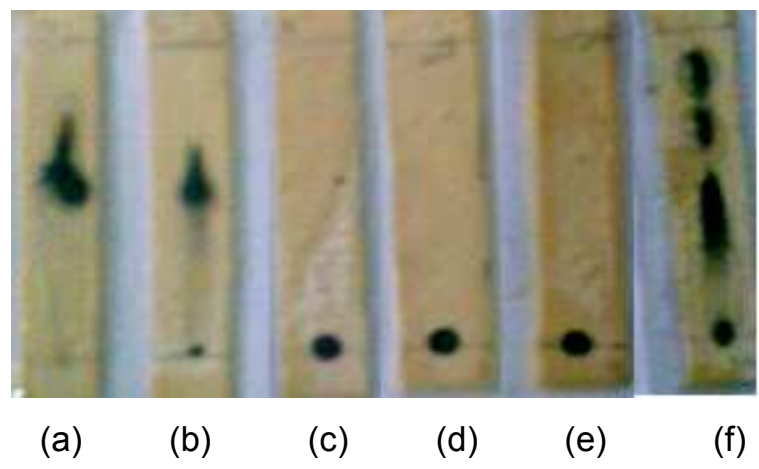

Gambar 1. Kromatogram Ekstrak Metanol Menggunakan Eluen Tunggal : (a) Metanol (b) Etanol (c) Kloroform (d) n-Heksana (e) Diklorometana (f) Etil asetat, dengan Penampak Noda $\mathrm{FeCl}_{3}$

Dapat dilihat bahwa, hanya pada eluen etil asetat saja ekstrak terelusi cukup baik yang menghasilkan pemisahan membentuk 3 noda. Untuk eluen etanol dan metanol, ekstrak dapat terelusi tetapi tidak menunjukkan adanya pemisahan. Sedangkan dengan eluen kloroform, n-heksana, dan diklorometana ekstrak tidak terelusi.

KLT dilanjutkan dengan pelarut campuran untuk memperoleh pemisahan yang lebih baik. Pencarian kondisi pelarut ini merupakan gabungan dari etil asetat dengan pelarut lain, hal ini dilakukan karena pada 


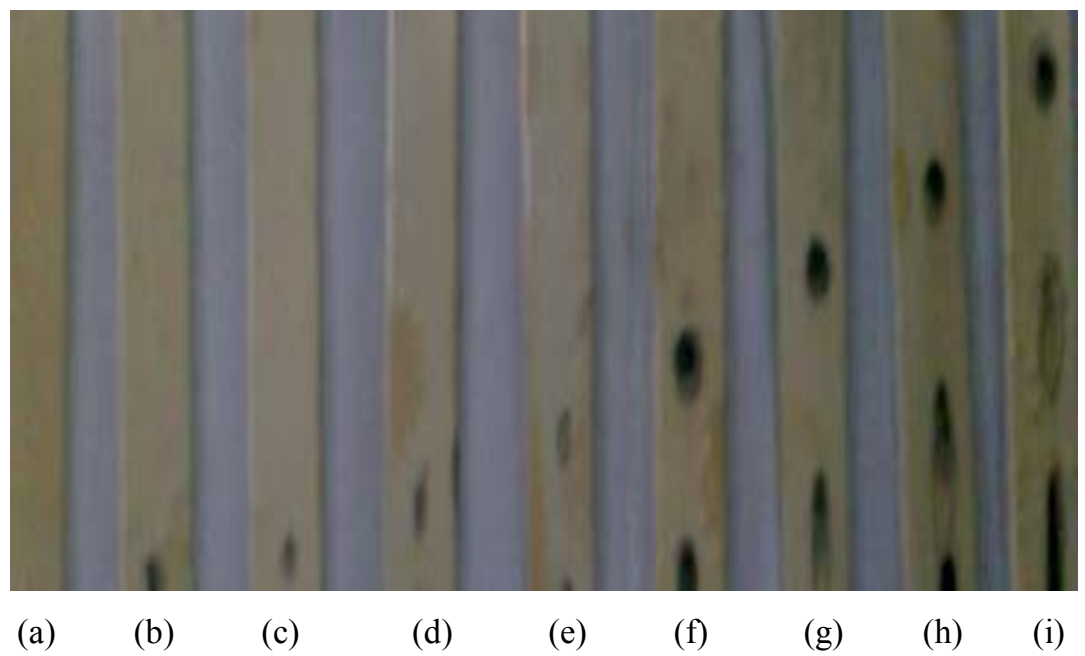

Gambar 2. Kromatogram ekstrak metanol menggunakan eluen etil asetat - kloroform dengan perbandingan : (a). 1:9 (b). 2:8 (c). $3: 7$ (d). 4:6 (e). 5:5 (f). 6:4 (g). 7:3 (h). 8:2 (i). 9:1.

Tabel 2. Uji aktivitas Antibakteri Ekstrak Metanol Biji Mangga Arum Manis dengan Bakteri E.coli dan S.aureus

\begin{tabular}{|c|l|c|c|}
\hline \multirow{2}{*}{ No } & \multirow{2}{*}{ Sampel $(\boldsymbol{\mu g}$ /disk) } & Diameter Zona & \multicolumn{2}{|c|}{ Hambatan (mm) } \\
\cline { 3 - 4 } & & Escherichia coli & Staphylococus aureus \\
\hline 1 & Ekstrak Metanol 7500 & 14 & 19 \\
\hline 2 & Ekstrak Metanol 3750 & 12 & 16 \\
\hline 3 & Ekstrak Metanol 1875 & 10 & 15 \\
\hline 4 & Tetrasiklin 30 & 23 & 30 \\
\hline 5 & Kloramfenikol 30 & 27 & 25 \\
\hline
\end{tabular}

kromatogram hasil KLT eluen tunggal etil asetat menunjukkan adanya pemisahan, tapi belum terpisah dengan baik karena bentuk noda yang dihasilkan belum membentuk bulatan dan masih memanjang. KLT dilanjutkan dengan menggunakan sistem eluen campuran dua pelarut yaitu : etil asetat dan kloroform dengan berbagai perbandingan. Hasil analisis KLT ini dapat ditunjukkan pada Gambar 2.

Elusi dengan eluen campuran ini menghasilkan pemisahan dengan dua atau tiga noda. Pada campuran etil asetat : kloroform dengan perbandingan 1:9, belum didapat pemisahan komponen. Pada campuran pelarut yang sama dengan perbandingan $2: 8,3: 7$, dan 4:6 kromatogram didapat pemisahan komponen dengan dua noda. Kemudian pada perbandingan 5:5, 6:4,
7:3, 8:2, dan 9:1 didapat pemisahan dengan tiga noda. Berdasarkan hasil kromatogram pada campuran pelarut ini didapatkan kondisi yang sesuai untuk pemisahan yang terbaik adalah pada perbandingan 8:2 yang ditunjukan dengan terpisahnya secara baik tiga noda dengan harga $\mathrm{Rf}$ masing-masing 0,$05 ; 0,45$ dan 0,78 .

Untuk mengetahui kandungan senyawa yang terdapat pada ketiga noda yang diperoleh, dilakukan analisis dengan pereaksi penampak noda yang sesuai dengan hasil uji fitokimia, yaitu : penampak noda $\mathrm{FeCl}_{3}$ untuk fenolik, Cerium Sulfat untuk flavonoid dan Liebermann Burchard untuk senyawa terpenoid. Uji ini memberikan hasil bahwa noda dengan harga $\mathrm{Rf}=0,05$ memberikan warna ungu tua dengan $\mathrm{FeCl}_{3}$ dan warna coklat dengan Cerium Sulfat yang 
menandakan noda ini mengandung senyawa golongan fenolik dan flavonoid. Noda dengan $\mathrm{Rf}=0,45$ memberikan warna ungu tua dengan $\mathrm{FeCl}_{3}$ dan warna kemerahan dengan Liebermann Burchard yang berarti bahwa noda ini mengandung senyawa golongan fenolik dan terpenoid. Selanjutnya noda dengan $\mathrm{Rf}=0,78$ hanya dengan $\mathrm{FeCl}_{3}$ bereaksi positif yaitu meberikan warna ungu tua yang menandakan noda ini mengandung senyawa golongan fenolik saja. Dari hasil analisis KLT ini dapat dinyatakan bahwa ekstrak metanol biji mangga harum manis sedikitnya mengandung 3 senyawa fenolik, 1 terpenoid dan 1 senyawa flavonoid

\subsection{Uji aktivitas Antibakteri}

Uji aktivitas antibakteri dilakukan untuk mengetahui apakah ektrak metanol biji mangga Arum manis dapat menghambat pertumbuhan bakteri Escherichia coli dan Staphylococus aureus. Uji aktivitas dilakukan dengan metoda cakram. Hasil uji aktivitas antibakteri dapat dilihat pada Tabel 2 .

Dari Tabel 2 di atas, terlihat ekstrak metanol biji mangga harum manis mampu menghambat pertumbuhan bakteri Escherichia coli dan Staphylococus aureus, yang ditunjukan dengan besarnya diameter zona hambatan yang dihasilkan untuk semua konsentrasi ekstrak sampel uji. Semakin besar konsentrasi ekstrak maka kemampuan menghambat pertumbuhan kedua jenis bakteri tersebut semakin kuat. Hal ini sesuai dengan Pelczar dan Chan (1988), bahwa semakin tinggi konsentrasi bahan antibakteri maka aktivitasnya semakin kuat pula. Namun demikian kemampuan menghambat pertumbuhan bakteri dari ekstrak metanol biji mangga Arum manis masih lebih rendah dibandingkan antibiotik tetrasiklin dan kloramfenikol. Hal ini dikarenakan ekstrak metanol biji mangga harum manis masih merupakan ekstrak kasar, sedangkan antibiotik tetrasiklin dan kloramfenikol merupakan senyawa sintetis yang dibuat untuk tujuan komersial sebagai antibiotik.

\subsection{Penetuan Konsentrasi Hambat Minimum}

Penentuan konsentrasi hambat minimum (KHM) dilakukan untuk mengetahui konsentrasi terendah dari ekstrak metanol yang masih dapat menghambat pertumbuhan bakteri E.coli dan S.aureus. Konsentrasi ekstrak yang dibuat berturut-turut adalah : 2000, 1000,500, 250 dan $125 \mu \mathrm{g} / \mathrm{mL}$. Hasil penentuan KHM dapat dilihat pada Tabel 3.

Tabel 3. Hasil Penentuan Konsentrasi Hambat Minimum Ekstrak Metanol Biji Mangga Arum Manis dengan Bakteri E.coli dan S,aureus

\begin{tabular}{|c|c|c|c|}
\hline No & $\begin{array}{c}\text { Ekstrak } \\
\text { Metanol } \\
(\mu \mathrm{g} / \mathrm{mL})\end{array}$ & E.coli & S.aureus \\
\hline 1 & 2000 & - & - \\
\hline 2 & 1000 & + & - \\
\hline 3 & 500 & + & - \\
\hline 4 & 250 & + & - \\
\hline 5 & 125 & + & + \\
\hline
\end{tabular}

Konsentrasi hambat minimum untuk E.coli diperoleh pada konsentrasi 2000 $\mu \mathrm{g} / \mathrm{mL}$, dimana pada konsentrasi ini tidak terjadi pertumbuhan E.coli. Sedangkan pada S.aureus didapatkan konsentrasi hambat minimum pada konsentrasi yang lebih kecil, yaitu pada $250 \mu \mathrm{g} / \mathrm{mL}$. Dengan demikian dapat disimpulkan bahwa ekstrak metanol biji mangga Arum manis lebih aktif menghambat pertumbuhan bakteri S.aureus dibandingkan dengan bakteri E.coli.

\section{Kesimpulan}

Biji mangga Arum manis (Mangifera indica Linn) mengandung senyawa metabolit sekunder golongan terpenoid, fenolik, dan flavonoid dengan kandungan tertinggi senyawa golongan fenolik. Ekstrak metanol biji mangga Arum manis mempunyai aktivitas menghambat pertumbuhan bakteri Escherichia coli dan Staphylococus aureus dengan konsentrasi hambat minimum masing-masing sebesar 2000 dan $250 \mu \mathrm{g} / \mathrm{mL}$. 


\section{Daftar Pustaka}

[1] Anonim. Statistik Pertanian Badan Pusat Statistik dan Direktorat Jenderal Hortikultura, Jakarta (2007).

[2] Colegate, S.M, and Molyneux, R.J. Bioactive Natural Products. CRC Press, London (1993).

[3] Harbone, J.B (Penerjemah : Kosasih Padmawinata dan Iwang Sudiro). Metode Fitokimia Penuntun Cara Modern Menganalisis Tumbuhan ITB, Bandung (1987)

[4] Adnan, Mochamad. Teknik Kromatografi Untuk Analisis Bahan Makanan ed. I, Yogyakarta (1997).

[5] Gibson, J.M., (Alih bahasa : Prasada, S.I.K.G). Mikrobiologi dan Patologi Modern Untuk Perawat. Penerbit Buku Kedokteran EGC, Jakarta (1996).

[6] Mustofa. Tinjauan Farmakologi Obat untuk Self Medication. Farmakologi / Pusat Kedokteran Tropis, Fakultas Kedokteran UGM Fitofarmaka, Yogyakarta (2007). 